\title{
Adult Users' Engagement and Utilisation of Social Networks Sites in Nigeria
}

\section{Rodney Ciboh, Benue State University, Makurdi, Nigeria.}

\begin{abstract}
Most studies on social media use in Nigeria focus on youths and address issues such as internet accessibility; frequency and extent of social networking sites use; political attitudes and online political participation; academic uses and news consumption, and the addiction to this form of media. Whilst youths are avid users, studies indicate that popularity of social media continues to grow among older adults of $65+$ years with multiple use rates. Hence this research describes the specific communication-based activities that occur on these sites among adults in Nigeria. The paper finds older Nigerians' communication on SNS disposed to bonding social capital as interactions skew towards family members, close friends and colleagues. And although only about three in ten adults' communication tends towards making new friends on social media, it concludes nonetheless that adult Nigerians' social interactions on SNS may yet have positive correlation with bridging social capital and its potential resources.
\end{abstract}




\section{Introduction}

The Internet technology has certainly revolutionized the world of communication. It has become not just a means of seeking information but of social relationships and interactions among other people, whether for business or commercial purposes, for making new friends, or for reconnecting with old friends and long lost relatives. Social networking sites or social media have particularly made it possible to develop social relations with people of similar interest and connect people across the globe without any geographic, economic or political barriers (Katz and Rice, 2002). Social networking sites have grown into powerful platforms that facilitate these social interactions and connections among families and friends across long distances and by which people share ideas, experiences, pictures, messages and information of interest (Ellison, Steinfield and Lampe, 2011).

Social networking has become part of the daily life experiences for an increasing number of people (Meyer and Bray, 2013; Kuppuswamy, \& Narayan, 2010; Gemmill, \& Peterson, 2006) especially young people. The popular image of young people is of them with their faces glued to screens while they are constantly texting, checking e-mail, or updating their Facebook pages and keeping up with world events and helping to shape them (Kacie, 2009). While social media use has grown dramatically among the youths, older users have been especially enthusiastic over the past few years about embracing new networking tools and now rely on social network platforms to help maintain contact with friends, families and colleagues, and manage their daily communications - sharing links, photos, videos, news and status updates (Bell, Fausset, Farmer, Nguyen, Harley and Fain, 2013).

Research on online social networks is vast but most of academic research has focused mainly on experiences of adolescents and young adults on these sites including social capital outcomes, probably to justify the popularity of SNS among undergraduate students or the college student population. There is currently little academic research that describes the activities of older adults on these sites (who does what and with whom) and how these behaviours affect outcomes of interest especially in Nigeria. In the research presented here therefore focused on older adults. Major objectives are to determine their awareness and understanding of social media, verify their frequency of use of these sites, validate modes of accessibility, and authenticate the most popular social network sites among them as well as purposes for using these social network sites. 


\section{Literature Review}

Although previous literature seems to indicate that new communication technologies such as computers, tablets and mobile phones, the Internet and online social technologies are underutilised by older people (Feist and McDougall, 2013), recent studies show that older adults who are aged 50 and above are fast adopting and utilizing social media to extend their social relationships and as part of their everyday life (Chakraborty, Vishik, and Rao, 2013; Phang, Sutanto, Kankanhalli, Li, Tan, and Teo, 2006; Selwyn, 2004).

While some studies suggest that older adults perceive the internet generally as an unwelcome place for sociality, and SNSs as places for people who seek publicity and superficial relationships (Lehtinen, Näsänen and Sarvas, 2009), other studies have shown that the percentage of adults of over 55 years online has nevertheless increased steadily (Fox, 2001, 2004; Demunter,2005). As of 2011, Chakraborty, Vishik, and Rao (2013) quote J. Carracher and Corbett3000, 2011 as reporting that there were approximately 16 million people 55 years and older, who were Facebook users.

In one of Pew Research Centre's Internet \& American Life Projects, Madden (2010) reports that growth of young adult internet and social networking sites use paled in comparison with the gains made by older users. Within a space of one year, she said, internet users of ages 5064 who said they use a social networking site like MySpace, Facebook or LinkedIn grew 88\% and those ages 65 and older grew 100\% in their adoption of the sites, compared with a growth rate of $13 \%$ for those ages $18-29$.

For most American senior internet users of ages 65 and older, Zickuhr and Madden (2012) say internet use is a daily feature in their lives with about $70 \%$ using the internet on a typical day and about $82 \%$ of all adult internet users going online on an average day overall. In one of Pew Research Center's Internet \& American Life Project, Rainie, Smith and Duggan (2013) say Facebook appeared the dominant social networking site in this country with about two-thirds of online American adults (67\%) saying they were Facebook users. According to Brenner and Smith (2013), percentage of online U.S. adults using social networking sites increased from $67 \%$ in late 2012 to almost three quarters (72\%) as of May 2013. 
An Ofcom (2014) report in the United Kingdom indicates that more UK adults, especially older adults, are now going online with over eight in ten $(83 \%)$ of adults now going online using any type of device in any location with the number of adults almost doubling from $16 \%$ in 2012 to $30 \%$ in 2013. In Australia, Feist and McDougall (2013) state that while the generation of older people aged 65 years and above had low rates of Internet adoption, those between the ages of 55 to 64 years had a much higher rate of Internet use.

All these researches suggest that although adolescents and young adults make up the majority of online social networkers, older populations are increasingly using sites such as Facebook and Twitter (Pfeil \& Zaphiris, 2010; Sum, Mathews, Pourghasem, and Hughes, 2008). Ostensibly, the fastest-growing group of the Internet and SNS users is people over 50 years and, as Lovett (2011) predicts, the number of older SNS users may grow significantly in the subsequent years. The most prominent functions on SNS sites are communication, picture sharing and entertainment, buying things, playing games (Joinson, 2008). Depending on computer skills and preferences of the individual involved, adults now go online using any type of device in any location using personal computers, tablets or mobile phones (Nef, Ganea, Müri, and Mosimann, 2013).

Studies investigating potential reasons for engaging with this kind of technology by older people suggest that connecting with friends and family remains the biggest reason to use a social networking site. That is, main benefit of using social networking sites for older adults is to enter in an intergenerational communication especially with younger family members (children and grandchildren (Nef, Ganea, Müri, and Mosimann, 2013). Interaction benefits of such intergenerational communication, Lindley, Harper and Sellen (2008) argue, support the maintenance of emotionally meaningful ties since older adults value their existing relationships more than new ties.

Aside from satisfying the need for social contact, several studies (Bradley \& Poppen, 2003; Farkas, 2010) suggest that online communication helps older people to prevent isolation and decrease loneliness. Selwyn (2004) notes other advantages of older adults using social networking sites as lower perceived life stress, and access to societal and health related information as well as avoidance of social isolation. Also, from their in-depth longitudinal studies of older people making use of social networking sites, Harley and Fitzpatrick (2011) 
identified six core (motivational) themes of relevance in relation to their appropriation of SNS: social contact; acquiring knowledge; supporting independence; intergenerational connection; reminiscence/life review and creativity. Nonetheless, Jones and Fox (2009) declare that most internet users aged 64+ go to web sites that provide information or support for a specific medical condition or personal situation. Either way, research seems to establish that online communication can enhance older people's quality of life and well-being (Xie, 2007).

Most of these studies have however been conducted in industrialized countries of Europe and America. That is, there is currently little empirical research that focuses specifically on adults' usage and interactions on these sites from Nigeria. But Nigeria is reputed to have the largest internet population in Africa and is 11th in the world (Internet World Stats, 2014). And Terragon Insights (2013) puts Internet penetration in Nigeria at $39.7 \%$ in 2013 up from $28.4 \%$ in 2012 and that the average Nigerian spends not less 3 hours on the internet daily. Corroboratory statistics released by market research and statistics specialists (Azeez, March $27,2014)$ show that Nigeria's internet connections have grown to about 200 per cent in the last four years spanning 2009 and 2013.

On use of SNS, Terragon Insights (2013) quotes data from Internet World Stats, June 2012, as putting social media penetration in Nigeria at around 5.4\% albeit young adults (age 15 to 34) demonstrate greater likelihood of being social network users than those 35 and older. And Nigeria's most frequently used SNS appeared to be Facebook, 2go, Twitter, Eskimi, Google+, Naij, Skype, Mobofree, Nairaland and Linkedin with top online activities among the older population being work and business/studies, email, news and information, social networking, downloads, entertainment (music, videos, gaming) and online shopping. A Gallup/BBG (2012) survey also found that sending or receiving email, finding the latest news, and updating a social networking profile are the most popular activities on the Internet among Nigerians.

Much of academic research in Nigeria has focused on activities of adolescent users and address issues such as why Nigerian students use of internet and social media (Sanusi, Buhari, Ibrahim and Bashir, 2014; Akindehin and Akindehin, 2011; Udende and Azeez, 2010; Adaja and Ayodele, 2013; Camilia, Ibrahim and Dalhatu (2013; Ojo and Madaki, 
2014). Others hub on news consumption (Oyero, 2013), while some explore extent of online political participation by youths on these social networks sites (Dagona, Karick, and Abubakar, 2013) as well as attitudes and addictions to these sites (Alabi 2013; Suleiman, 2012). Some studies have drawn attention to patterns of social media-arranged-gender-based violence among youths in Nigeria (Idongesit, 2014; Radda and Ndubueze, 2013). With little on experiences of older adults on these sites and how these affect outcomes of interest among them. The current study tries to fill this gap by focusing on experiences of adult SNS users, rather than adolescent users. Our work investigates the use of SNS by older people. In particular, we are interested in the major activities that consume the time of older adults on these sites and possibly the reasons why they engage in such activities on SNS.

\section{Methodology}

In order to investigate how older people use social network sites, we tried to establish our use of the term "older people" as a frame of reference for this study. But defining "old" is difficult and age classification varies among countries and over time (Seeman, Lusignolo Berkman and Albert, 2001). Thus, for a working definition for this study, we adopted the chronological age of 45 years since the World Health Organisation (2012) puts life expectancy in Nigeria at less than 55 years.

To analyze how older people use social network sites and what benefits they derive from them, a survey of older adults living in the metropolitan Makurdi, capital of Benue State was conducted to understand the characteristics of older adults who do and do not use SNS. Using purposeful sampling, we collected information about demographics and other descriptive variables, including gender, age, occupation, income, education, ethnic group. A purposeful sampling became necessary for face value validation of the age of respondents prior to administration of instruments.

Structured questionnaires were employed to collect data from a representative sample of 400 adults. A total of 395 filled in questionnaires were received back, which comes to an overall response rate of 98.75 per cent. The data were analysed and inferences were made based on standard statistical methods. 


\section{Findings}

As illustrated in Figure 1 below, internet use varies considerably by age and gender. Internet use is more prevalent among males than females almost in the ratio of three to one female. That is, females appeared almost three times less likely $(27.8 \%)$ than males $(69.7 \%)$ to go online or use social networking sites. It is probable that this significant difference between male and female users may not be unconnected with gender inequality determined largely by African/Nigerian culture where females have fewer opportunities to do what they want without intervention from family or any person responsible from them (A'lamElhuda and Dimetry, 2014).

Figure 1: Demographics of older adults using the internet

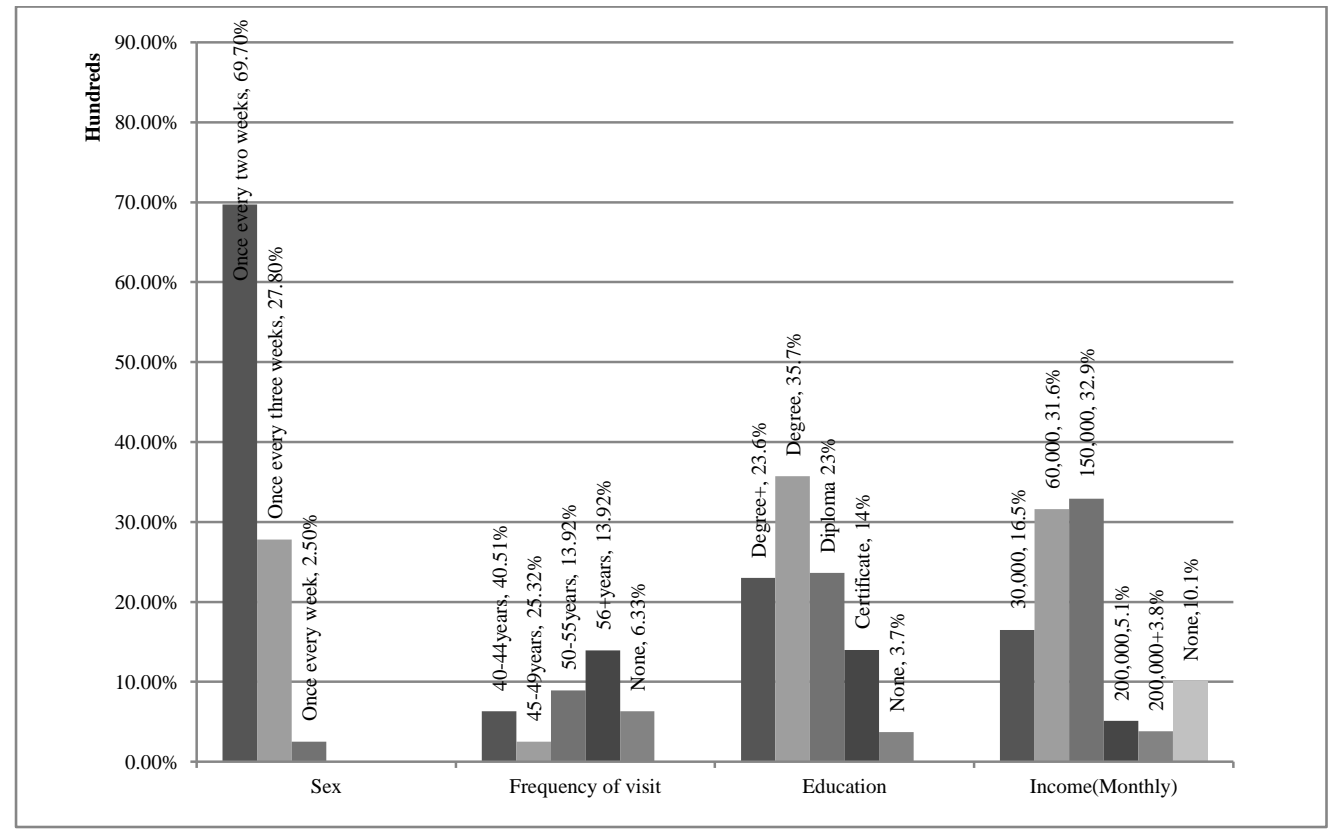

Internet use varies considerably and daily internet use appears to decline by age. Among those 50-55 and 56 years older, only about one in every ten (13.92\%) use the internet compared to four in every ten $(40.51 \%)$ of those ages $40-44 \mathrm{~s}$ and almost three in ten (25.32\%) of 45-49s. This means there is strong likelihood that younger people will continue to be the heaviest users of the internet social networking sites. Overall, $93.67 \%$ of all adults ages 40 and older say they use the internet or SNS, albeit $6.33 \%$ t refused to share their experiences in his regard. Invariably, older people who do use the internet tend to do so less frequently than younger people (Berry, 2011). 
Internet access certainly depends on socioeconomic status. Those with more than a primary education appeared more than 6 times as likely as those with a primary education or less to have used the Internet. Although income does not appear to define internet use here, those with middle level income are about three times (64.5\%) as likely to report using the Internet as those who earn below and above $(25.4 \%)$ them. Similarly, those who have attained higher levels of education - first degree and above - appeared far more likely to use the internet and SNS than those who are not. Research has also shown that internet use tends to be lower among people with lower incomes and lower educational attainment, disabled people, single parents, female homemakers and people living in rural communities (Räsänen, 2006; Wong et al, 2009).

Figure 2: Internet and SNS modes of access and frequency of use

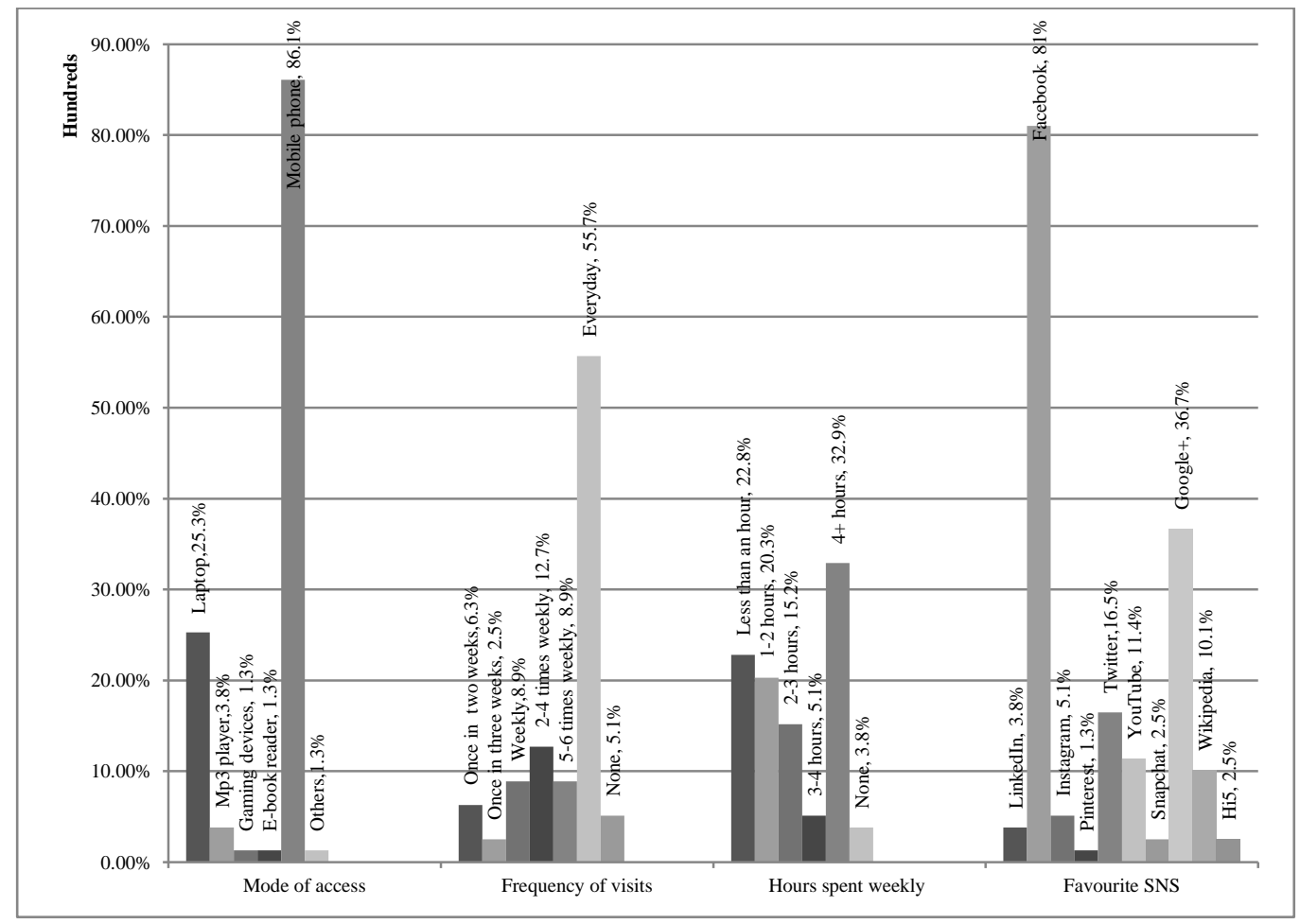

Figure 2 shows that older people are spending an average of one and a half hours weekly online. Of these, about one in every five said they do spend up to 2 hours online or less. And while nearly one sixth of all adults sampled spend between 2 to 3 hours online, approximately one-third reported spending more than four hours weekly online or that they spend as long time as they can online and on their favourite social network sites. For the majority, the internet and social network sites are a daily part of life. That is, over half $(55.7 \%)$ of the 
sampled adults visit social networking sites daily. Conversely, this means at least one in two adult is a "heavy" social media user, meaning they use at least two different types of social media each and every day.

As illustrated in Figure 2 above, most adults sampled are using several devices to go online. While at least one in every four adult uses the PC or laptop to go online, the most common device to access the internet is the mobile phone. Use of mobile phone of any kind among all adults is almost universal at $86.1 \%$. This use of alternative devices like games console $(3.8 \%)$, portable media player and E-book reader $(1.3 \%)$ and other devices appears supplemental to using a mobile phone or PC/laptop.

Data on usage shows a very high level of awareness and understanding of social media is amongst Nigerian adults. Same as among the younger generation, findings reveal that Facebook is the most popular and widespread social media site accounting for about $81 \%$ active Nigerian adult users. Following almost by half is Google+ (36.7\%), then Twitter (16.5\%), and YouTube (11.4\%) closely followed by Wikipedia (10.1\%). Few members of the older adult population seem to use Instagram, LinkedIn and others.

Figure 3: Older adults' motivations for using the Internet and SNS

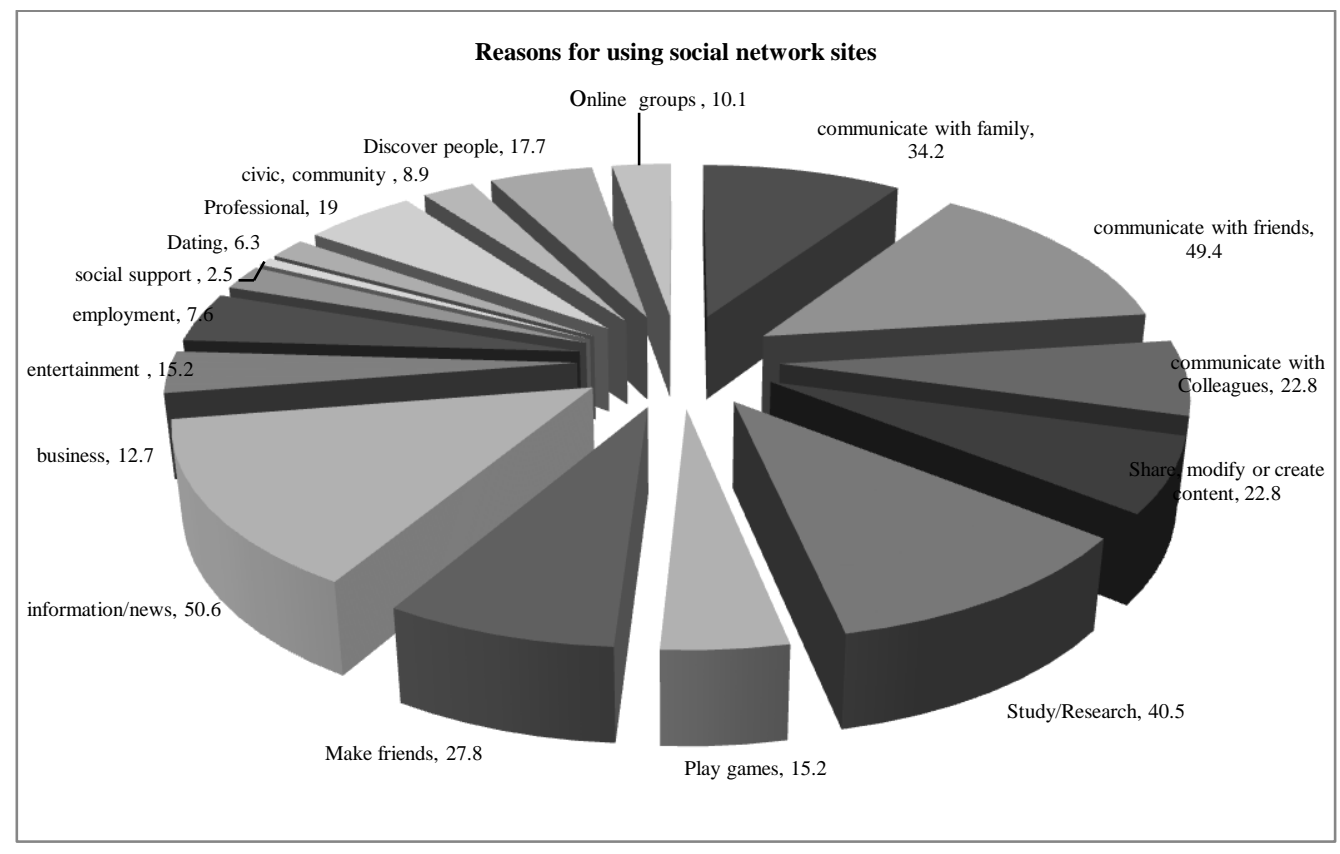


Results from figure 3 suggest that many older adults use social network sites primarily to be informed of current issues and events (50.6\%) and for research or studies (40.5\%), followed closely by communication with friends $(49.4 \%)$ and family (34.2\%). About one in five adult Nigerian sampled said they use social media to make friends $(27.8 \%)$, communicate with colleagues and said share or create content (22.8\%). Only about one in every six of the adults said they use social network sites either to play games, or for entertainment or professional purposes. These results show that an average Nigerian adult on social networking sites primarily seeks information and updates their knowledge and equally communicate with friends and family members. But the average adult Nigerian SNS user desires to communicate with friends, family and colleagues and make new friends almost twice as much as he/she would seek information and research online. Overall, an average Nigerian adult's social networking activities revolve around communicating with friends, family and colleagues and making new friends.

\section{Discussion of Findings}

This research was conducted to find out the level of awareness and use of social media especially the purposes for which older adults use these social network sites. This became necessary against the backdrop that most of academic research has focused mainly on experiences of adolescents and young adults on these sites with little academic research describing the activities of older adults on these sites and their points of interest especially in Nigeria.

Findings confirm a strong correlation between age and usage. There is growing evidence that older age groups are becoming more active online, those relatively younger demonstrated greater possibility than older people to use the internet and social networking sites more frequently (Berry, 2011). As among the younger users, internet use varies considerably by gender being more prevalent among males than females probably. This tendency is perhaps best explained by gender inequality that is quite prevalent in African/Nigerian culture where females have fewer opportunities to do what they want without intervention from family or any person responsible from them (A'lamElhuda and Dimetry, 2014).

Among older adults, Internet and social media use seems defined by socio-economic variables like level of education and income. While we may argue that income does not 
define internet use in absolute terms, those with higher levels of education appeared to use the internet and SNS than those who are not. Invariably, research has also shown that internet use tends to be lower among people with lower incomes and lower educational attainment, disabled people, single parents, female homemakers and people living in rural communities (Räsänen, 2006; Wong et al, 2009).

Frequency of use, modes of access and time spent online by older people do not appear to vary greatly among the younger generation. For most adults, the internet and social network sites are a daily part of life. Results show nearly one in two adults is a "heavy" internet or social media user, meaning they spend an average of more than four hours weekly or as long time as they can online and on their favourite social network sites. Also, they exploit at least two different types of social media each and every day using several devices to go online. The traditional PC or laptop is gradually giving way to the trendier mobile phone as commonest device to access the internet and social sites. Although alternative devices like games console, portable media player and E-book reader exist, these appear supplemental to the mobile phone and PC/laptop.

As among the younger generation and as Rainie, Smith and Duggan (2012) say, Facebook remains the most popular and widespread social media site among Nigerian adults with eight out of ten active users. And while other sites like Google+, Twitter, YouTube and Wikipedia have relatively fair share of usage, older adult traffic decreased on sites like Instagram, LinkedIn and others. Overall, major activities on these sites by older adults seemed to revolve around communicating with friends and family members as well as for information resource and research with relatively few straying into online games, entertainment or professional exploits. Invariably, the biggest reason of using social networking sites for older adult Nigerians remains connecting with friends and family suggestive of an intergenerational communication (Nef, Ganea, Müri, and Mosimann, 2013) which, Lindley, Harper and Sellen (2008) argue, support the maintenance of emotionally meaningful ties since value their existing relationships more than new ties.

\section{Conclusion}

In this paper, we have attempted to broaden our knowledge of older adults' social network site use through both their activities on these sites and what implications and gains. Overall, 
older Nigerian adults' communication interactions on SNS seemed inclined to building and maintaining social relationships that are constitutive of bonding social capital is found between individuals in tightly-knit, emotionally close relationships, such as family, close friends and colleagues. But because at about three in ten sampled said they use social media to make friends, it seems plausible to conclude that adult Nigerians' social interactions on SNS nevertheless support loose social ties and augment bridging social capital from which they could potentially draw resources. It is our hope that this work will contribute to our understanding of older adults' activities on social networks especially in Nigeria but we suggest further research into real and potential benefits such interactions garner for the older population especially the social capital implications. 


\section{References}

Adaja, T. A. and Ayodele, F. A. (2013). Nigerian youths and social media: harnessing the potentials for academic excellence. Arabian Journal of Business and Management Review Vol. 2, No.5; Jan. 2013 Retrieved August 29, 2014 from http://www.arabianjbmr.com/pdfs/KD_VOL_2_5/8.pdf

Alabi, O. F. (2013). A survey of facebook addiction level among selected Nigerian university undergraduates New Media and Mass Communication Retrieved August 29, 2014 from http://www.iiste.org/Journals/index.php/NMMC/article/viewFile/4533/4606

A'lam Elhuda, D. and Dimetry, D. A. (2014). The Impact of Facebook and Others Social Networks Usage on Academic Performance and Social Life among Medical Students at Khartoum University .International Journal of Scientific \& Technology Research, 3, 5, pp. 41-46.

Akindehin, F. and Akindehin, M. (2011). Online social networking practices of some Nigerian university undergraduates: Implications for counselling. British Journal of Arts and Social Sciences ISSN: 2046-9578, Vol.3 No.1. Retrieved August 29, 2014 from http://www.bjournal.co.uk/paper/BJASS_3_1/BJASS_03_01_06.pdf

Azeez, K. (March 27, 2014). Nigeria's internet access grows $200 \%$ in four years. Retrieved 26th April, 2009from http://nationalmirroronline.net/new/nigerias-internet-accessgrows-200-in-four-years/

Bell, C., Fausset, C., Farmer, S., Nguyen, J., Harley, L., Fain, W. B. (2013). Examining social media use among older adults. Proceedings of the $24^{\text {th }}$ ACM Conference on Hypertext and Social Media (pp. 158-163).

Berry, R. (2011). Older people and the internet :Towards a "system map" of digital exclusion. International Longevity Centre - UK. Retrieved 24th April, 2009 from http://www.ilcuk.org.uk/files/pdf_pdf_181.pdf

Bradley, N. \& Poppen, W. (2003). Assistive technology, computers and Internet may decrease sense of isolation for homebound elderly and disabled persons. Technology and Disability, 15(1), 19-25.

Brenner, J. and Smith, A. (2013). 72\% of Online Adults are Social Networking Site Users. Retrieved April 14, 2015 from http://www.pewinternet.org/files/oldmedia/Files/Reports/2013/PIP_Social_networkin g_sites_update_PDF.pdf 
Chakraborty, R., Vishik, C. and Rao, H. R. (2013). Privacy preserving actions of older adults on social media: Exploring the behaviour of opting out of information sharing. Decision Support Systems 55, 948-956. http://dx.doi.org/10.1016/j.dss.2013.01.004. Retrieved April 13, 2015 from http://www.cse.buffalo.edu/caeiae/documents/pdf/chakraborty-dss-2013.pdf

Dagona, Z. K., Karick, H. and Abubakar, F. M. (2013). Youth participation in social media and political attitudes in NigeriaJournal of Sociology, Psychology and Anthropology in Practice, Vol. 5, No. 1, Retrieved August 29, 2014 from http://www.icidr.org/Jspap_Vol5_No1_April2013/Youth\%20Participation\%20in\%20 Social\%20Media\%20and\%20Political\%20Attitudes\%20in\%20Nigeria.pdf

Demunter, C. (2005). The Digital Divide in Europe. Statistics in Focus 38/2005. Eurostat, Luxembourg. Retrieved April 13, 2015 from http://ec.europa.eu/eurostat/documents/3433488/5572700/KS-NP-05-038EN.PDF/15d4a86b-929e-4757-bcf5-ad0e1502a387?version=1.0

Ellison, N. B., Steinfield, C. and Lampe, C. (2011). Connection Strategies: Social Capital Implications of Facebook-enabled Communication Practices. New Media \& Society, $13,6,873-892$

Farkas, P. A. (2010). Senior Social Platform - An Application Aimed to Reduce the Social and Digital Isolation of Seniors. In Proceedings of REAL CORP, Vienna.

Feist, H. and McDougall, K. (2013). Older People's Use of New Communication Technologies: Research Findings \& Policy Implications Australian Population \& Migration Research Centre Policy Brief, Vol. 1, No. 8 Retrieved April 12, 2015 fromhttps://www.adelaide.edu.au/apmrc/pubs/policybriefs/APMRC_Policy_Brief_Vo 1_1_8_2013.pdf

Fox, S. (2001). Wired Seniors: A Fervent Few, Inspired by Family Ties. Pew Foundation, Washington, D.C. Retrieved April 13, 2015 from http://www.pewinternet.org/2001/09/09/wired-seniors/

Fox, S. (2004). Older Americans and the Internet. Pew Foundation, Washington, D.C. Retrieved April 13, 2015 from http://www.pewinternet.org/2004/03/28/olderamericans-and-the-internet/

Gallup/BBG (2012). Nigeria Media Use 2012. Retrieved 24th April, 2009 from http://www.bbg.gov/wp-content/media/2012/08/gallup-nigeria- brief.pdf 
Gemmill, E., \& Peterson, M. (2006). Technology use among college students: Implications for studentaffairsprofessionals. NASPA Journal, 43(2), 280-300.

Harley, D. and Fitzpatrick, G. (2011). Appropriation of social networking byolder people: two case studies. ECSCW Workshop/Conference on Fostering Social Interactions in the Ageing Society: Artefacts - Methodologies - Research Paradigms. Retrieved April 13, 2015 from

http://www.researchgate.net/publication/230785755_Appropriation_of_social_networ king_by_older_people_two_case_studies

Idongesit, E. (2014). Youths, social media and gender-based violence: an emerging trend in Nigeria? International Journal of Economy, Management and Social Sciences, 3, 1, 21-27.

Internet world stats, (June 2014). Internet Usage Statistics for Africa: Africa Internet Usage and 2014 Population Stats. Retrieved 24th April, 2009 from http://www.internetworldstats.com/stats1.htm

Joinson, A. N. (2008). Looking at, Looking up or Keeping up with People? Motives and Use of Facebook (pp. 1027-1036). In Proceedings of ACM CHI 2008 Conference on Human Factors in Computing Systems. New York: ACM.doi:10.1145/1357054.1357213.

Jones, S., and Fox, S. (2009). Generations online. Washington, DC: Pew Internet \&American Life Project, 2009. Retrieved 13th June, 2009 fromhttp://www.pewinternet.org/ /media//Files/Reports/2009/PIP_Generations_2009. pdf

Kacie D. (2009). Use of "Social Networks" Strengthen Impact of Pro-Life Youth, National Rights to a Life (NRL) News Page 9, January 2009, Volume 36,Issue 1

Katz, J. E. and Rice, R. E. (2002).Social Consequences of Internet Use: Access, Involvement, and Interaction. Cambridge, MA: MIT Press

Kuppuswamy, S., \& Narayan, P. B. (2010). The Impact of Social Networking Websites on the Educationof Youth. International Journal of Virtual Communities and Social Networking (IJVCSN), 2(1), 67-79.

Rainie, L., Smith, A. and Duggan, M. (2013). Coming and Going on Facebook. Retrieved April 12, 2015 from http://pewinternet.org/Reports/2013/Coming-and-going-onfacebook.aspx 
Lehtinen, V., Näsänen, J. and Sarvas, R. (2009). “A Little Silly and Empty-Headed” - Older Adults' Understandings of Social Networking Sites Proceedings of the 23rd British HCI Group Annual Conference on People and Computers: Celebrating People and Technology Pages 45-54. Retrieved April 13, 2015 from http://www.bcs.org/upload/pdf/ewic_hci09_paper6.pdf

Lindley, S. E., Harper, R., and Sellen, A. (2008). Designing for Elders: Exploring the Complexity of Relationships in Later Life. In Proc. HCI 2008 -People and Computers XXIII - Culture, Creativity, Interaction, 77-86.

Lovett, G. (2011). Over 50s drive facebook growth. Marketing Week. Available at: http://www.marketingweek.co.uk/over50s-drive-facebook-growth-studysays/3027863.article. http://www.marketingweek.com/2011/06/27/over-50s-drivefacebook-growth-study-says/

Madden, M. (2010). Older Adults and Social Media . Retrieved April 12, 2015 from http://www.pewinternet.org/2010/08/27/older-adults-and-socialmedia/

Meyer, M. D.E. and Bray, C. W. (2013). Emerging Adult Usage of Social Networks as Sites of Activism: A Critical Examination of the TOMS and TWLOHA Movements. Ohio Communication Journal Volume 51, pp.5377http://cnu.edu/communication/profiles/meyer/pdf/04_2014.pdf

Nef, T., Ganea, R. L., Müri, R. M. and Mosimann, U. P. (2013). Social networking sites and older users - a systematic reviewInternational Psychogeriatrics. doi:10.1017/S1041610213000355 . Retrieved April 13, 2015 fromhttp://www.cclm.unibe.ch/unibe/philhuman/cclm/content/e200922/e200932/e273 258/linkliste273259/Nefetal.-2013-

Socialnetworkingsitesandolderusersasystem_ger.pdf.

Ofcom (2014). Adults' Media Use and Attitudes Report, . Retrieved April 12, 2015 from http://stakeholders.ofcom.org.uk/binaries/research/media-literacy/adults2014/2014_Adults_report.pdf

Ojo, F. Y. and Madaki, F. (2014). Computer ownership, accessibility and usage of internet and social media among undergraduates in Ekiti state, Nigeria International Journal of Research, Education and Academic Development (IJOREAD) Vol.3 No. 1 Retrieved August 29, 2014 from http://www.spreadng.org/ijoread/Ijoread\%20vol3b.pdf 
Oyero, o. (2013). The use and believability of social networks news among Nigerian youths. Covenant Journal of Communication Vol. 1, No. 12013 Retrieved August 29, 2014 from http://journals.covenantuniversity.edu.ng/cjoc/published/Oyero2013.pdf

Pfeil, U. \& Zaphiris, P. (2010) Investigating social network patterns within an empathic online community for older people. Computers in Human Behavior, 25(5), p. 11391155.

Phang, C., Sutanto,J., Kankanhalli, A., Li,Y., Tan, B. and Teo, H. (2006). "Senior Citizens' Adoption of E-Government: In Quest of the Antecedents of Perceived Usefulness", HICSS, 2005, 2014 47th Hawaii International Conference on System Sciences, 2014 47th Hawaii International Conference on System Sciences 2005, pp. 130a, doi:10.1109/HICSS.2005.538. Retrieved April 13, 2015 from http://www.computer.org/csdl/proceedings/hicss/2005/2268/05/22680130a-abs.html

Radda, S. I. and Ndubueze, P. N.(2013). Fear of on-line victimization among undergraduate students: a comparative study of two selected urban universitiesAfrican Journal of Criminology and Justice Studies,7,1\&2 Retrieved August 29, 2014 from http://www.umes.edu/cms300uploadedFiles/AJCJS/Volume_7_Issue_1_and_2/VOL7 $.1 \% 20 \mathrm{RADDA} \% 20 \mathrm{FINAL} . \mathrm{pdf}$

Räsänen, P (2006). Information Society For All? Structural Characteristics of Internet Use in 15 European Countries ${ }^{e e}$,European Societies, 8 (1), pp.59-81

Rainie, L., Smith, A., \& Duggan, M. (2013). Coming and going on Facebook. Pew Research Center's Internet \& American Life Project. Retrieved 18 ${ }^{\text {th }}$ May, 2015 from http://www.pewinternet.org/2013/02/05/coming-and-going-on-facebook/

Sanusi R., Buhari G., Ibrahim A. and Bashir H. A. (2014) Use of social media among students of Nigerian Polytechnics. Presented at the International Conference on Communication, Media, Technology and Design 24 - 26 April 2014, Istanbul Turkey. Retrieved August 29, 2014 from http://www.cmdconf.net/2014/pdf/47.pdf

Seeman TE, Lusignolo T, Berkman L, Albert M. (2001). Social Environment Characteristics and Patterns of Cognitive Aging: MacArthur Studies of Successful Aging.Health Psychology 20:243-255.

Selwyn, N. (2004) The information aged: a qualitative study of older adults' use of information and communications technology, Journal of Aging Studies 18 (4) 369384. 
Suleiman, A. A.(2012). Attitudinal disposition of nigerian university students toward social networking SITES. International Journal of Emerging Technologies in Learning Vol 7, No 1 Retrieved August 29, 2014 from http://online-journals.org/index.php/ijet/issue/view/135

Sum, S., Mathews, M. R., Pourghasem, M., \& Hughes, I. (2008). Internet technology and social capital: How the internet affects senior's social capital and wellbeing. Journal of Computer-Mediated Communication, 14, 202-220.

Terragon Insights, (2013). State of digital media nigeria. Retrieved 24th April, 2009 from http://www.africapractice.com/wp-content/uploads/2014/04/Africa-Practice-SocialMedia-Landscape-Vol-1.pdf

Udende, P. and Azeez, A. L. (2010). Internet access and use among students of the University of Ilorin, NigeriaJournal of Communication and Media Research. Retrieved August 29, 2014 from https://unilorin.edu.ng/publications/udendep/Internet\%20access\%20and\%20use $\% 20 \mathrm{a}$ mong\%20students.pdfVol. 2 No. 1 Pages $33-42$

WHO Report (2012). WHO African Region: Nigeria Retrieved 26th April, 2009 from http://www.who.int/countries/nga/en/

Wong, Y, Fung, J, Law, C, Lam, J \& Lee, V (2009).Tackling the digital divide ${ }^{e e}$ British Journal of Social Work, 39, pp.754-767

Xie, B. (2007). Older Chinese, the Internet, and well-being. Care Management Journals:Journal of Long Term Home Health Care, 8(1), 33-38.

Zickuhr, K. and Madden, M. (2012). Older adults and internet use. Retrieved April 13, 2015 from http://pewinternet.org/Reports/2012/Older-adults-and-internet-use.aspx 